\title{
A FAIRER, SAFER, AND MORE JUST SYSTEM FOR ALL NEW YORKERS: DOMESTIC VIOLENCE AND NEW YORK BAIL REFORM
}

\author{
HANNAH GUTENPLAN*
}

\begin{abstract}
On January 1, 2020, bail reform laws went into effect in New York that eliminated cash bail for thousands of defendants across the state. In step with other reforming jurisdictions across the country, New York aimed to ensure that a defendant's freedom before trial would not be determined by the individual's ability to pay. Unlike other reforming jurisdictions, however, New York's bail laws do not include public safety as a legitimate factor for judges to consider when setting release conditions. Some domestic violence advocates have expressed concern for victims' safety during the pretrial period in domestic violence cases. This Note explores the potential impact of New York's bail reform laws on domestic violence cases and whether any mitigating measures may be implemented to promote victims' safety.
\end{abstract}

\section{INTRODUCTION}

On January 1, 2020, New York State's criminal justice reform went into effect, aiming to create a more just system through speedy trial, discovery, and bail reform laws. ${ }^{1}$ Each part of the reform bill is designed to work together to address mass incarceration in New York's jail and prison system by lowering reliance on incarceration while maintaining public safety. ${ }^{2}$ In particular, the bail reform laws eliminate cash bail for most defendants so that defendants are no longer detained before trial solely due to

\footnotetext{
* J.D. Candidate 2021, Columbia Law School; B.A. 2015, Columbia University. The author would like to thank Professor Kellen Funk for his guidance in writing this Note, as well as the staff of the Columbia Journal of Gender and Law for their thoughtful comments and edits.

${ }^{1}$ Governor Andrew Cuomo's office characterizes New York's criminal justice reform as “[c]reating a fairer, safer, and more just system for all New Yorkers.” Criminal Justice Reform, OfF. WeBsite OF N.Y. ST., https://www.governor.ny.gov/programs/criminal-justice-reform [https://perma.cc/NNH4-BRP7].

${ }^{2}$ See id.
} 
their inability to pay the bail amount. ${ }^{3}$ Overall, the criminal justice reform bill aims to reduce the prison population in New York State without sacrificing safety. ${ }^{4}$

In recent years, a movement to end mass incarceration has gained prominence across the country. Civil rights litigator and legal scholar Michelle Alexander published The New Jim Crow: Mass Incarceration in the Age of Colorblindness more than ten years ago, propelling the issue of overincarceration of predominantly young Black and Hispanic men to the national stage. ${ }^{5}$ Mass incarceration has been called "the civil rights crisis of our time" ${ }^{\prime 6}$ and combatting mass incarceration has become a political bipartisan issue. $^{7}$

Pretrial detention contributes significantly to mass incarceration in the United States. Local jails today contain more people awaiting trial than people who have been convicted

\footnotetext{
${ }^{3}$ See id. ("Bail reform eliminates cash bail for most defendants to ensure an individual's wealth is no longer the determining factor for pretrial detention while awaiting their day in court.").

${ }^{4}$ See id. ("Under Governor Cuomo's leadership, New York will continue to push progressive reforms to maintain New York's status as the safest large state in the nation, without an unnecessary and counterproductive reliance on incarceration.”).

${ }^{5}$ Michelle AleXander, The New Jim Crow: Mass InCarceration in the Age of Colorblindness (2010). See generally David Remnick, Ten Years After “The New Jim Crow,” New Yorker (Jan. 17, 2020), https://www.newyorker.com/news/the-new-yorker-interview/ten-years-after-the-new-jim-crow [https://perma.cc/S7XD-RBXK].

${ }^{6}$ Michael Waldman \& Adureh Onyekwere, Ending Mass Incarceration: Ideas from Today's Leaders, BRENNAN CTR. FOR JUST. (May 16, 2019), https://www.brennancenter.org/our-work/policy-solutions/endingmass-incarceration-ideas-todays-leaders [https://perma.cc/8CRQ-5ZZB].

${ }^{7}$ According to a national survey of registered voters, three-quarters of Americans believe the criminal justice system needs significant improvements, including $68 \%$ of Republicans, $78 \%$ of Independents, and $80 \%$ of Democrats. Memorandum from Robert Blizzard, Public Opinion Strategies to Interested Parties, National Poll Results (Jan. 25, 2018), https://www.politico.com/f/?id=00000161-2ccc-da2c-a963-efff82be0001 [https://perma.cc/R2M9-ZSMC]. In 2017, U.S. Senators Kamala Harris (D-CA) and Rand Paul (R-KY) introduced a bail reform bill titled the Pretrial Integrity and Safety Act. Pretrial Integrity and Safety Act of 2017, S. 1593, 115th Cong. (2017). Top Democratic candidates for the 2020 election released criminal justice plans and in 2018, President Donald Trump signed into law the First Step Act, a criminal justice reform act that had bipartisan support. See Timothy Williams \& Thomas Kaplan, The Criminal Justice Debate Has Changed Drastically. Here's Why., N.Y. Times (Aug. 20, 2019),

https://www.nytimes.com/2019/08/20/us/politics/criminal-justice-reform-sanders-warren.html [https://perma.cc/V8WN-PJYQ].
} 
of a crime. ${ }^{8}$ Many of those detained pretrial are held merely because they cannot afford to pay the bail amount for their release. ${ }^{9}$ New York State is just one jurisdiction that has pursued criminal justice reform by addressing the cash bail system. In August 2018, thenGovernor Jerry Brown signed legislation to abolish California's cash bail system, ${ }^{10}$ although a statewide referendum has since stalled the legislation from going into effect. ${ }^{11}$ In 2017, the New Jersey Criminal Justice Reform Act took effect, moving New Jersey's pretrial system from a predominantly cash bail system to a risk-based system. ${ }^{12}$ Civil rights groups have filed lawsuits in federal courts across the country, attacking municipal bail systems. ${ }^{13}$ In 2017, the Federal District Court in the Southern District of Texas granted a preliminary injunction, enjoining Harris County's misdemeanor bail system-

\footnotetext{
${ }^{8}$ See Peter Wagner \& Wendy Sawyer, Mass Incarceration: The Whole Pie 2020, Prison PoL'y Initiative (Mar. 24, 2020), https://www.prisonpolicy.org/reports/pie2020.html [https://perma.cc/PTC9-Q26S] (estimating over 555,000 people are held in pretrial detention in the United States).

${ }^{9}$ See id. ("The median bail amount for felonies is $\$ 10,000$, which represents 8 months' income for a typical person detained because they can't pay bail.").

${ }^{10}$ See Vanessa Romo, California Becomes First State to End Cash Bail After 40-Year Fight, NPR (Aug. 28, 2018), https://www.npr.org/2018/08/28/642795284/california-becomes-first-state-to-end-cash-bail [https://perma.cc/49VN-63FM].

${ }^{11}$ See Patrick McGreevy, Prop. 25, Which Would Have Abolished California's Cash Bail System, Is Rejected by Voters, L.A. Times (Nov. 3, 2020), https://www.latimes.com/california/story/2020-11-03/2020-californiaelection-prop-25-results; see also Julia Wick, Newsletter: The Future of Cash Bail in California, L.A. TIMES (Jan. 23, 2020), https://www.latimes.com/california/story/2020-01-24/cash-bail-boudin-san-francisconewsletter [https://perma.cc/WWC4-EJ7F]; California Proposition 25, Replace Cash Bail with Risk Assessments Referendum (2020), BALLOTPEDIA,

https://ballotpedia.org/California_Proposition_25,_Replace_Cash_Bail_with_Risk_Assessments_Referendu m_(2020) [https://perma.cc/6NSA-AFKT].

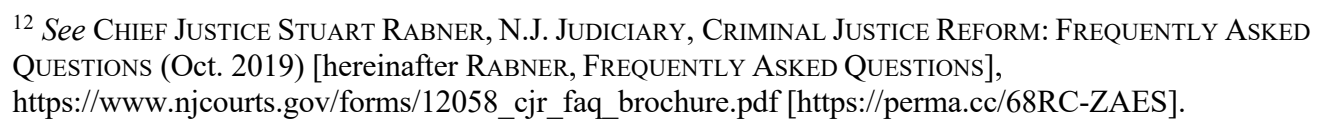

${ }^{13}$ See, e.g., Class Action Complaint, Allison v. Allen, No. 1:19-cv-01126 (M.D.N.C. Nov. 12, 2019), https://www.aclu.org/legal-document/complaint-14 [https://perma.cc/H2HN-LMDG]; Complaint, Walker v. City of Calhoun, 2015 WL 13547012 (N.D. Ga. Dec. 2, 2015) (No. 4:15-cv-170-HLM), https://cdn.buttercms.com/qovLB95TzKuS2V2KDUAJ [https://perma.cc/6SZC-UK4Z]; Class Action Complaint, Torres v. Collins, 2020 WL 2465516 (E.D. Tenn. Apr. 14, 2020) (No. 2.20-cv-00026), https://cdn.buttercms.com/Vmiu8Q3RuaQT8xFRODIb [https://perma.cc/ZSF8-NLUF].
} 
the third largest bail system in the country-from detaining defendants who are unable to afford money bail. ${ }^{14}$

Many reforming jurisdictions aim to eliminate or decrease judges' reliance on cash bail but allow judges to either set bail or impose pretrial detention if there is a risk to public safety. ${ }^{15}$ An increasing number of jurisdictions use risk assessments to determine whether a defendant should be released. ${ }^{16}$ The goal in the risk-based reform model is twofold: to ensure that (1) low risk defendants are not detained pretrial merely because they cannot afford to pay bail and (2) high risk defendants are not released merely because they can afford to pay bail. ${ }^{17}$ For example, New Jersey's criminal justice reforms move the state's system away from cash bail by instructing courts to make pretrial release decisions based on a public safety assessment. ${ }^{18}$ New York is noteworthy for its move away from cash bail without incorporating a consideration of public safety in pretrial release decisions. ${ }^{19}$ New York's criminal justice reform eliminates cash bail for most

\footnotetext{
${ }^{14}$ ODonnell v. Harris Cnty., 251 F. Supp. 3d 1052 (S.D. Tex. 2017), aff'd as modified, 892 F.3d 147 (5th Cir. 2018); see Kellen Funk, The Present Crisis in American Bail, 128 YALE L.J.F. 1098, 1101 (2019).

${ }^{15}$ See, e.g., Consent Decree at 17-20, ODonnell, 251 F. Supp. 3d 1052, aff'd as modified, 892 F.3d 147 (No. 16-cv-01414), https://cdn.buttercms.com/tp3B1dAWT5y3k0nHmHJk [https://perma.cc/84UZ-D7KV] (allowing judicial officers to order pretrial detention for those arrested on misdemeanors that fall within certain categories if there are no conditions of release that would assure public safety); N.M. R. CRIM. P. §5409 ("Notwithstanding the right to pretrial release ... the district court may order the detention pending trial of a defendant charged with a felony offense if the prosecutor files a motion titled 'Expedited Motion for Pretrial Detention' and proves by clear and convincing evidence that no release conditions will reasonably protect the safety of any other person or the community.").
}

${ }^{16}$ Sandra G. Mayson, Dangerous Defendants, 127 YALE L.J. 490, 492-93 (2018) [hereinafter Mason, Dangerous Defendants]; see Arnold Ventures, Public Safety FAQs ("PSA 101") (Mar. 18, 2019), https://craftmediabucket.s3.amazonaws.com/uploads/Public-Safety-Assessment-101_190319_140124.pdf [https://perma.cc/8Q8A-UCXU] (reporting that the Arnold Ventures public safety assessment is used statewide in Kentucky, Arizona, New Jersey, and Utah and is used in a number of major cities and surrounding areas, including Cook County (Chicago), Illinois; Harris County (Houston), Texas; Maricopa County (Phoenix), Arizona; San Francisco County, California; Mecklenburg County (Charlotte), North Carolina; Allegheny County (Pittsburgh), Pennsylvania; Lucas County (Toledo), Ohio; Minnehaha County (Sioux Falls), South Dakota; Milwaukee County, Wisconsin; Santa Cruz County, California; and New Orleans, Louisiana).

${ }^{17}$ See Timothy Schnacke, Nat'l Ctr. for State Cts., The Third Generation of Bail Reform 10 (2017); Mayson, Dangerous Defendants, supra note 16, at 492-93.

${ }^{18}$ See generally the discussion of New Jersey's pretrial laws, infra Part I.B.2.a.

${ }^{19}$ Insha Rahman, Vera Inst. of Just., New York, New York: Highlights of the 2019 Bail Reform Law 6 (2019), https://www.vera.org/downloads/publications/new-york-new-york-2019-bail-reform-law- 
misdemeanors and non-violent felonies, subject to some exceptions, ${ }^{20}$ and includes a presumption of release rebuttable only by a "risk of flight to avoid prosecution.".21

New York State has taken a significant step toward addressing injustices in the bail context, but some domestic violence advocates criticize the reform out of concern that the new pretrial regime may pose risks for victims of domestic violence. ${ }^{22}$ Thousands of New Yorkers report incidents of domestic violence to law enforcement each year. ${ }^{23}$ Police intervention has the potential to disrupt a cycle of escalating violence, ${ }^{24}$ and some domestic violence advocates credit bail with providing a mechanism to buy time for the victim to exit a dangerous situation and seek help. ${ }^{25}$ When an offender is merely

highlights.pdf [https://perma.cc/E8NT-HMUD] ("New York was, and remains, the only state in the country that precludes judges from taking into account any consideration of public safety when setting bail or imposing pretrial detention."). But see Mayson, Dangerous Defendants, supra note 16, at $516 \mathrm{n} .120$ ("New York is often said to exclude consideration of dangerousness, but it does authorize courts to issue protective orders as conditions of release, and other aspects of its pretrial law also suggest otherwise.").

${ }^{20}$ Michael Rempel \& Krystal Rodriguez, Ctr. For Ct. Innovation, Bail Reform in New York: Legislative Provisions ANd IMPLiCATIONS FOR NEW York City 2 (2019) [hereinafter ReMPEL \& RODRIGUEZ, BAIL REFORM IN NEW YORK], https://www.courtinnovation.org/sites/default/files/media/document/2019/Bail_Reform_NY_full_0.pdf [https://perma.cc/6AXA-TL5J].

${ }^{21} I d$. at 5.

${ }^{22}$ See, e.g., Judy Harris Kluger \& Ariel Zwang, Reform Bail While Protecting Victims: How to Strike the Right Balance in New York's Latest Criminal Justice Reform Push, N.Y. DaILY News (Mar. 21, 2019), https://www.nydailynews.com/opinion/ny-oped-reform-bail-while-protecting-victims-20190321qge3hi7jvjcj5a65h716ixh33m-story.html.

${ }^{23}$ In 2018, police agencies outside of New York City reported 26,860 assaults by intimate partners and responded to 182,893 domestic incidents. N.Y. State OfF. FoR the Prevention of Domestic Violence, New York State Domestic Violence Dashboard 2018, at 2 (Oct. 2019), https://opdv.ny.gov/statistics/nydata/docs/opdv-2018-dv-dashboard.pdf [https://perma.cc/5E67-PDKJ].

${ }^{24}$ A statewide study by the New York State Office of Domestic Violence Prevention on the effectiveness of mandatory arrest on recidivism concluded that "mandatory arrest, along with the issuance of an order of protection, dramatically affected the rate of recidivism." Lisa Fischel-Wolovick, Police Response: Mandatory Arrest \& Primary Physical Aggressor, in Lawyer's Manual on Domestic Violence: RePResenting the Victim 57 (Mary Rothwell Davis et al. eds., 6th ed. 2015) (quoting N.Y. State OfF. OF Domestic Violence Prevention, Evaluation of DVia Mandatory Arrest Provisions: Final Report (2001)).

${ }^{25}$ See Rachel Louise Snyder, No Visible Bruises: What We Don't Know About Domestic Violence CAN Kill Us 236-37 (2019). 
processed and released after arrest, however, he is free to return to the victim. ${ }^{26}$ When the offender and victim share a residence, that may be the most natural - if not the onlyplace to go. The immediate release of a violent offender may signal that abuse is not taken seriously as a criminal matter, which may discourage victims from reporting truly dangerous situations. When a change in law has the potential to affect thousands of cases, it is important to evaluate whether the new regime may have unintended consequences that endanger victims' safety.

The recent New York bail reform has the potential to leave some New Yorkers vulnerable to violence during the period between arrest and trial. This Note explores the possible impact of the reform on victims of domestic violence and whether such impact may be reduced through legislative changes or changes in judicial practice. Part I reviews the history of bail and the development of bail reform. It looks at the reform measures in New Jersey as a point of comparison. It also presents the New York bail reform scheme. Part II identifies and explores the ways in which the New York bail reform laws may leave victims vulnerable to violence. Finally, Part III presents potential mitigating measures that could be incorporated into New York's pretrial scheme.

\section{Background}

The administration of bail determines whether a criminal defendant will be released or detained in the time between arrest and trial. In a typical case, a defendant is arrested and arraigned before a judge. ${ }^{27} \mathrm{~A}$ judge sets bail, and if the defendant can post bail or pay a bondsman to post bail, they are released. ${ }^{28}$ If the defendant is unable to post bail, they are detained in jail. ${ }^{29}$ The traditional theory behind this process is that the payment of bail will ensure the defendant's appearance at trial. ${ }^{30}$ The linking of monetary payment and appearance at trial, however, is not an obvious move and contributes to inequities in bail

\footnotetext{
${ }^{26}$ Some domestic violence advocates credit bail as an imperfect mechanism to keep high-risk defendants away from the victim. Kluger \& Zwang, supra note 22 ("As experts in our legal system and in working with victims, we know that cash bail, though a flawed system, has become a stand-in way for judges to protect victims. It allows them to keep high-risk defendants in jail, and away from the victim, before a trial.”).

${ }^{27}$ See, e.g., Arraignments, NYCOURTS.GOv [hereinafter NYCOURTS.GOv, Arraignments], https://www.nycourts.gov/courthelp/Criminal/arraignments.shtml [https://perma.cc/T2UJ-HBVP].

${ }^{28}$ See, e.g., Bail, NYCOURTS.GOV, https://www.nycourts.gov/courthelp/Criminal/bail.shtml [https://perma.cc/JJ4P-MG6Q].

${ }^{29} \mathrm{Id}$.

${ }^{30}$ See Daniel J. Freed \& Patricia M. Wald, Bail in the United States: 1964, at vii (1964).
} 
administration. ${ }^{31}$ Part I.A recounts the historical background of bail to understand how the bail doctrine developed in the United States and why we may question its continued use. Part I.B presents the current state of bail in the United States. Part I.C introduces the New York bail reforms.

\section{A. History of Bail Reform}

The practice of setting money bail to ensure a defendant's return to court traces its roots back to medieval England, when the Anglo-Saxon legal system transitioned to a process of settling private disputes by monetary payment rather than blood feuds. ${ }^{32}$ To guard against the risk of the defendant fleeing before trial, the legal system required a personal surety - usually a defendant's friend or family member - to pledge to guarantee the defendant's appearance at trial and the payment of the fine. If the accused fled, the surety paid the accuser, rendering a trial unnecessary. ${ }^{33}$ Following the Norman conquest, capital and corporal punishment replaced money fines for many offenses. ${ }^{34}$ Nevertheless, because the incentive to flee before trial remained, courts continued to require money bail even after the bail amount was divorced from the underlying fee.

When the colonists settled in America, they imported much of English law, including the laws surrounding bail administration and the practice of releasing defendants prior to trial. ${ }^{35}$ The Supreme Court confirmed in Stack v. Boyle that the purpose of bail was to assure the defendant returns to court. ${ }^{36}$ The Court held that bail set higher than the

\footnotetext{
${ }^{31}$ See generally discussion infra Part I.B.

${ }^{32}$ Money fines, called "bots," were used to compensate private grievances. TIMOTHY R. SCHNACKE, MiCHAEL R. Jones \& Claire M. B. Brooker, Pretrial Just. Inst., The History of Bail and Pretrial Release 1 (2010) (citing June Carbone, Seeing Through the Emperor's New Clothes: Rediscovery of Basic Principles in the Administration of Bail, 34 SYRACuSE L. Rev. 517, 519-20 (1983)).

${ }^{33} I d$. at 2.

${ }^{34}$ June Carbone, Seeing Through the Emperor's New Clothes: Rediscovery of Basic Principles in the Administration of Bail, 34 SyraCuSE L. Rev. 517, 521 (1983).

${ }^{35}$ SCHNACKE, JONES \& BROOKER, supra note 32, at 4.

${ }^{36}$ Stack v. Boyle, 342 U.S. 1, 5 (1951) (holding that, "[1]ike the ancient practice of securing oaths of responsible persons to stand as sureties for the accused, the modern practice of requiring a bail bond or the deposit of a sum of money subject to forfeiture serves as additional assurance of the presence of an accused").
} 
amount needed to do so was "excessive" under the Eighth Amendment. ${ }^{37}$ Bail developed to mirror the trial outcome in the early English system but it is worth considering whether monetary payment is the best way to accomplish the goals of the pretrial system when a guilty defendant's trial outcome is a jail or prison sentence. ${ }^{38}$ Subsequent reform movements in the twentieth century reflect the difficulties of a pretrial system tied to wealth, whether the movements are concerned with the inequitable administration of bail or with public safety concerns.

Concerns about inequitable bail practices motivated the bail reform movement in the mid-twentieth century. In the 1950s, Caleb Foote studied the administration of bail in New York and Philadelphia and concluded that bail amounts were tied to the severity of the offense rather than ability to pay, leading to many defendants being unable to post bond. ${ }^{39}$ Beginning in 1961, the Vera Foundation and the New York University Law School studied alternatives to money bail bonds under the Manhattan Bail Project. Data from the Manhattan Bail Project indicated that money bail was not necessary to assure a defendant's return to court. ${ }^{40}$ Based on these findings, Congress passed the Bail Reform Act of 1966, which codified a presumption of pretrial release, introduced non-monetary conditions as an alternative to money bonds, and included "community ties" as a consideration for setting pretrial release conditions. ${ }^{41}$

\footnotetext{
${ }^{37} I d$.

${ }^{38}$ Law Professor June Carbone notes, "The Anglo-Saxon bail process was perhaps the last entirely rational application of bail." Carbone, supra note 34, at 520 (quoted by SCHNACKE, JONES \& BROOKER, supra note 32, at 2). In New York, the median amount of bail varies significantly across the state. In New York City, bail was $\$ 1,000$ or less for most misdemeanor cases in which bail was set. In Buffalo, the median bail amount set was \$5,000. RAHMAN, supra note 19, at 6 (first citing Russell F. FERri ET AL., N.Y.C. CRIM. Just. AGENCY, ANNUAL REPORT 2016, at 21 (2018), https://www.nycja.org/assets/CJA_Annual_Report_2016-1.pdf [https://perma.cc/KC5W-9KXX]; and then citing ANDREA Ó SúILLEABHÁin \& COLLEEN KRISTICH, CRUELTY AND COST: MONEY BAIL IN BufFALO 5 (2018), https:/ppgbuffalo.org/files/documents/criminaljustice/cruelty_and_cost_money_bail_in_buffalo.pdf [https://perma.cc/8TJ2-WJSY]).

${ }^{39}$ Carbone, supra note 34, at 552 (citing CAleb Foote, Studies on BAil 8, 43, 79-81, 190 (1966)).

${ }^{40}$ Vera staffers developed a point system for measuring community ties to measure the likelihood of a defendant returning to court. The study showed that only $1.6 \%$ of defendants released without bond willfully failed to appear in court, compared to $3 \%$ of those released on bail. Id. at 553 .
}

${ }^{41} I d$. 
By the 1970s, the public grew increasingly concerned about public safety and crime, including crime committed by people out on bail. ${ }^{42}$ In 1984, Congress passed the Bail Reform Act of 1984, which introduced a consideration of public safety in the federal system and allowed for the denial of bail based on a consideration of future dangerousness. ${ }^{43}$ Though the Supreme Court had emphasized the "traditional right to freedom before conviction" in Stack v. Boyle ${ }^{44}$ the Court upheld the 1984 Act's preventative detention provision in United States v. Salerno against Due Process and Eighth Amendment challenges. ${ }^{45}$ The Court explained, "We believe that when Congress has mandated detention on the basis of a compelling interest other than prevention of flight, as it has here, the Eighth Amendment does not require release on bail." ${ }^{46}$ Although the 1984 Act applied only to the federal bail system, the Court's holding in Salerno established the constitutionality of public safety considerations when setting bail and preventative pretrial detention. Some jurisdictions have relied on those tools to address domestic violence concerns in the bail context. ${ }^{47}$

\section{B. The State of Bail Today}

The bail reforms of the twentieth century authorized judges to release defendants on their own recognizance and impose non-financial conditions of release. The reforms also sanctioned legislation introducing public safety considerations in the pretrial release decision. Nevertheless, many jurisdictions failed to fully embrace these measures and continued to rely primarily on money bail as a release condition and use unaffordable bail

\footnotetext{
${ }^{42}$ SCHNACKE, JONES \& BOOKER, supra note 32, at 17.

${ }^{43} I d$. at 18. The 1984 Act required "pretrial release of the person on personal recognizance, or upon execution of an unsecured appearance bond in an amount specified by the court . . unless the judicial officer determines that such release will not reasonably assure the appearance of the person as required or will endanger the safety of any other person or community.” Bail Reform Act of 1984, 18 U.S.C. § 3142(b).

${ }^{44} 342$ U.S. 1, 4 (1951).

${ }^{45}$ United States v. Salerno, 481 U.S. 739 (1987).

${ }^{46}$ Id. at $754-55$.

${ }^{47}$ See discussion infra Parts I.B.2, III.
} 
for de facto detention. ${ }^{48}$ Thus, despite the bedrock principle of the presumption of innocence ${ }^{49}$ defendants may be jailed before a finding of guilt due to bail practices. ${ }^{50}$

Besides offending notions of justice, pretrial detention imposes tangible costs on defendants. Defendants detained before trial may be induced to accept plea deals, even if they are innocent, because to do otherwise may mean spending months in jail before trial ${ }^{51}$ Resulting criminal records subsequently impact employment, housing, and education. ${ }^{52}$ The Supreme Court has said that "pretrial confinement may imperil the suspect's job, interrupt his source of income, and impair his family relationships." Moreover, the negative effects of pretrial detention are not merely theoretical. Empirical studies show that pretrial detention affects case outcomes and the likelihood of recidivism. A study of misdemeanor cases in Harris County, Texas, found that defendants detained before trial are $25 \%$ more likely to be convicted and $43 \%$ more likely to be sentenced to jail than similarly situated defendants who were released before trial. ${ }^{54}$ The same study also showed that detained defendants had longer sentences and were more likely to commit future crimes compared to similarly situated released defendants. ${ }^{55} \mathrm{~A}$ study using data from Philadelphia court records found that defendants detained pretrial

\footnotetext{
${ }^{48}$ Mayson, Dangerous Defendants, supra note 16, at 507.

${ }^{49}$ See Coffin v. United States, 156 U.S. 432, 453 (1895) ("The principle that there is a presumption of innocence in favor of the accused is the undoubted law, axiomatic and elementary, and its enforcement lies at the foundation of the administration of our criminal law."); see also James Q. Whitman, Presumption of Innocence or Presumption of Mercy?: Weighing Two Western Modes of Justice, 94 TEX. L. Rev. 933, 933-34 (2016) (characterizing the American criminal justice system as built on a presumption of innocence, in contrast with criminal justice systems in continental Europe, which are oriented toward a presumption of mercy).

${ }^{50}$ See Wagner \& Sawyer, supra note 8.

${ }^{51}$ Pretrial Justice Reform, AM. C.L. Union (ACLU) N.J., https://www.aclunj.org/theissues/criminaljustice/pretrial-justice-reform [https://perma.cc/796H-P8PK]; see also Paul Heaton et al., The Downstream Consequences of Misdemeanor Pretrial Detention, 69 Stan. L. Rev. 711, 715-16 (2017) (reasoning that pretrial detention for misdemeanor charges is particularly likely to induce guilty pleas because prosecutors often offer sentences for "time served" or probation for pleading guilty, leading to immediate release upon a guilty plea).

${ }^{52}$ See ACLU N.J., supra note 51.

${ }^{53}$ Gerstein v. Pugh, 420 U.S. 103, 114 (1975).

${ }^{54}$ See Heaton et al., supra note 51, at 717.

${ }^{55}$ See id. at 717-18.
} 
are $13 \%$ more likely to be convicted, have sentences that are $42 \%$ longer, and owe $41 \%$ more in non-bail court fees. ${ }^{56}$ Studies show that bail practices disproportionately affect Black and Hispanic defendants ${ }^{57}$ and lower income people. ${ }^{58}$ This section addresses the current bail reform movement and New Jersey's reform as representative of the current movement.

\section{The Risk-Based Approach}

This generation of bail reform ${ }^{59}$ has been characterized as a campaign to shift wealthbased pretrial systems - the traditional bail regime - to risk-based systems ${ }^{60}{ }^{6}$ In a wealthbail system, defendants who may be "low risk" may be incarcerated before trial because they cannot afford the bond payment while "high risk" defendants who can afford bail are released on bond.$^{61}$ The model risk-based system avoids tying a defendant's release to his or her financial resources. Instead, the court would make a release decision and set nonfinancial release conditions based on an assessment of the defendant's risk and likelihood

\footnotetext{
${ }^{56}$ See Megan Stevenson, Distortion of Justice: How the Inability to Pay Bail Affects Case Outcomes, 34 J.L. ECON. \& ORG. 511, 512-13 (2018).

${ }^{57}$ See Stephen DeMuth, Racial and Ethnic Differences in Pretrial Release and Decisions and Outcomes: A Comparison of Hispanic, Black, and White Felony Arrestees, 41 CRIMINOLOGY 873, 895 (2003) (finding that the likelihood of pretrial detention is $66 \%$ greater for Black defendants than white defendants and $91 \%$ greater for Hispanic defendants than white defendants after studying pretrial release outcomes for over 30,000 felony defendants charged with property, violent, and drug crimes); see also Cynthia E. Jones, "Give Us Free": Addressing Racial Disparities in Bail Determinations, 16 Legis. \& PuB. PoL'y 919, 938 (2013) ("Over the last fifty years, research studies have consistently found that African American defendants receive significantly harsher bail outcomes than those imposed on white defendants.").

${ }^{58}$ Bernadette Rabuy \& Daniel Kopf, Prison Pol’y Initiative, Detaining the Poor: How Money Bail Perpetuates an Endless Cycle of Poverty and Jail Time (May 10, 2016) https://www.prisonpolicy.org/reports/incomejails.html [https://perma.cc/FV3K-FJSL].

${ }^{59}$ Criminal justice analyst Timothy Schnacke has dubbed today's bail reform movement "the third generation of bail reform." SCHNACKE, supra note 17, at 8. In 1985, Professor John Goldkamp identified the previous two movements as formal "generations" of bail reform. John S. Goldkamp, Danger and Detention: A Second Generation of Bail Reform, 76 J. CRIM. L. \& CRIMINOLOGY 1, 1-5 (1985).

${ }^{60}$ Mayson, Dangerous Defendants, supra note 16, at 508.

${ }^{61}$ SCHNACKE, supra note 17, at 10.
} 
of returning to court. ${ }^{62}$ Jurisdictions across the country are increasingly incorporating risk assessments into their pretrial system. ${ }^{63}$ The risk-based approach lends itself particularly well to domestic violence considerations because it acknowledges public safety as a valid consideration for pretrial release decisions and accepts the premise of pretrial detention for certain classes of defendants. ${ }^{64}$

There are, however, risks of racial bias in administering a risk-based system. Judicial determinations of risk are subject to judges' cognitive biases. ${ }^{65}$ To combat this bias, jurisdictions have incorporated risk assessments as an objective scientific approach to assessing risk. Risk assessments are actuarial tools that use input factors to predict the likelihood of a certain outcome, usually re-arrest. ${ }^{66}$ However, even if the inputs are not

\footnotetext{
62 See generally Pretrial Just. Inst., What Pretrial Systems Look Like Without Money Bail (2017), https://university.pretrial.org/HigherLogic/System/DownloadDocumentFile.ashx?DocumentFileKey=5abb91 b8-5dad-3554-b9c4-74fdf417dbea\&forceDialog=0 [https://perma.cc/AQ24-DBDR].

${ }^{63}$ See generally Pretrial Just. Inst., What's HapPening in Pretrial Justice? (2020) [hereinafter Pretrial Just. Inst., What's Happening in Pretrial Justice?], https://university.pretrial.org/HigherLogic/System/DownloadDocumentFile.ashx?DocumentFileKey=086b04 0f-92b3-d72f-7692-1131693fe666\& forceDialog $=0$ [https://perma.cc/48S4-Y6RJ]. In Indiana, Criminal Rule 26 took effect in January 2020, requiring courts to release arrestees who do not present "a substantial risk of flight or danger to themselves or others." $I d$. at 13. To determine the arrestee's risk of flight or danger, courts are instructed to use evidence-based risk assessments. Id.; see also IND. R. CRIM. P. 26. In Michigan, the state supreme court launched a pilot program in five district courts to implement a pretrial risk assessment tool. "No Michigan residents should be sitting in jail just because they can't afford to pay their bail," said Chief Justice Bridget M. McCormack in support of the pilot program. "Our goal is to help judges make bond decisions that protect rights, enhance public safety, strengthen communities, and save money." PRETRIAL Just. Inst., What's Happening in Pretrial Justice?, supra, at 7; see also Press Release, Michigan Courts, Pilot Program Aims to Improve Public Safety, Protect Rights, and Reduce Jail Costs (Feb. 14, 2019), https://courts.michigan.gov/NewsEvents/press_releases/Documents/Pretrial\%20risk\%20assessment\%20pilot\%20media\%20release\%20FINAL. pdf [https://perma.cc/ANQ2-NHCG].

${ }^{64}$ See infra Parts I.B.2 and III.A.

${ }^{65}$ Sandra G. Mayson, Bias In, Bias Out, 128 YALE L.J. 2220, 2278 (2019).

${ }^{66}$ Id. at 2221.
} 
explicitly racial, the inputs may be correlated with race. ${ }^{67}$ Nevertheless, risk assessments predict recidivism in defendants with increasing accuracy and sophistication. ${ }^{68}$

\section{The New Jersey Model}

New Jersey's criminal justice reform, which went into effect in January 2017, is one of the most prominent examples of successful statewide implementation of the risk-based approach. The legislation incorporates some provisions addressing domestic violence; an Attorney General Directive lays out a pretrial framework directly addressing domestic violence advocates' critiques. This section lays out the New Jersey bail reform measures and how New Jersey addresses considerations of domestic violence in the pretrial context.

\section{a. New Jersey Bail Reform Generally}

On January 1, 2017, New Jersey overhauled the state's pretrial system ${ }^{69}$ moving away from money bail to a risk-based system, in which courts consult a risk assessment tool to make release decisions. In March 2013, researchers found that defendants held pretrial accounted for three-quarters of the jail population in New Jersey. ${ }^{70}$ Just over 5,000 inmates, or nearly $40 \%$ of the total jail population, could not afford to post bail for their release. ${ }^{71}$ In response to these findings, the Chief Justice of New Jersey's Supreme Court, Stuart Rabner, appointed the Joint Committee on Criminal Justice, which included prosecutors, public defenders, the attorney general, judges, and state government representatives. The committee released a report containing recommendations that led to

${ }^{67}$ See generally Bernard E. Harcourt, Risk as a Proxy for Race: The Dangers of Risk Assessment, 27 FED. SENT'G REP. 237 (2015).

${ }^{68}$ Mayson, Dangerous Defendants, supra note 16, at 497; Zhiyuan “Jerry” Lin et al., The Limits of Human Predictions of Recidivism, SCI. ADVANCES, Feb. 2020, at 5 (2020) (finding that risk assessments outperform human predictions of recidivism in real world-like scenarios where there is extensive background information, there is no immediate feedback, and base rates of recidivism are not balanced).

${ }^{69}$ RABNER, FreQUently AsKed Questions, supra note 12.

${ }^{70}$ Marie VanNostrand, Luminosity \& the Drug Policy Alliance, New Jersey Jail Population ANALYSIS 11 (2013), https://www.drugpolicy.org/sites/default/files/New_Jersey_Jail_Population_Analysis_March_2013.pdf [https://perma.cc/2J6T-3XGN]; see also Bryce Covert, The "Humble Beginnings" of the Sweeping Bail Reforms Enacted by New Jersey, THE APPEAL (Oct. 30, 2017), https://theappeal.org/the-humble-beginningsof-the-sweeping-bail-reforms-enacted-by-new-jersey-a2cab5dd3870/ [https://perma.cc/BA3P-8SVW].

${ }^{71}$ VANNostRAND, supra note 70, at 13 ; see also Covert, supra note 70. 
a 2014 state constitutional amendment, the 2017 bail reform legislation, and the creation of pretrial services agency. ${ }^{72}$

Implementing a risk-based approach required a constitutional amendment to authorize pretrial detention. ${ }^{73}$ In November 2014, New Jersey voters approved a state constitutional amendment that removed language granting a right to bail in criminal cases. The new amendment authorized courts to order pretrial detention without bail for high-risk defendants. ${ }^{74}$ The courts make risk determinations according to the procedures set out in the 2017 criminal justice reform legislation.

Under the new statute, the Administrative Director of the Courts must approve the risk assessment instrument, which must be "objective, standardized, and developed based on analysis of empirical data and risk factors relevant to the risk of failure to appear in court when required and the danger to the community while on pretrial release." ${ }^{, 75} \mathrm{New}$ Jersey courts currently use a public-safety assessment tool (PSA) designed by the Laura and John Arnold Foundation (now Arnold Ventures), ${ }^{76}$ a philanthropy focused on four issue areas - criminal justice, education, health, and public finance - and guided by evidence-based policy, research, and advocacy ${ }^{77}$ The PSA uses nine risk factors to evaluate the risk of the defendant's failure to appear, the risk of new criminal activity, and the risk of new violent criminal activity ${ }^{78}$ The risk factors include measures of the

\footnotetext{
${ }^{72}$ N.J. Joint Comm. on Crim. Just., Report of the Joint Committee on Criminal Justice (2014), https://www.njcourts.gov/courts/assets/criminal/finalreport3202014.pdf [https://perma.cc/QF3M-L8WN].

${ }^{73} I d$. at 4.

${ }^{74}$ New Jersey Pretrial Detention Amendment, Public Question No. 1 (2014), BallotPedia, https://ballotpedia.org/New_Jersey_Pretrial_Detention_Amendment,_Public_Question_No._1_(2014) [https://perma.cc/FV3E-29B3].

${ }^{75}$ N.J. Stat. AnN. § 2A:162-25(c)(1) (West 2020).

${ }^{76}$ ACLU N.J., supra note 51.

77 About, ARNOLD VeNTURES, https://www.arnoldventures.org/about [https://perma.cc/6UT5-C4PT]; Stanford L. SCh. Pol'y Lab, Risk Assessment Factsheet: Public SAFETy AsSessment (PSA) (May 10, 2019), https://www-cdn.law.stanford.edu/wp-content/uploads/2019/05/PSA-Sheet-CC-Final-5.10-CCUpload.pdf [https://perma.cc/5DMS-ZSSQ].

${ }^{78}$ N.J. Cts., Public Safety Assessment: New Jersey Risk Factor Definitions 1 (Dec. 2018), https://njcourts.gov/courts/assets/criminal/psariskfactor.pdf [https://perma.cc/EDZ7-XL24].
} 
defendant's age, the nature of the arrest, the nature of prior arrests, and past failures to appear pretrial, among other measures. ${ }^{79}$

The new system incorporates the risk assessment tool at multiple points in the arrest process. First, at the time of arrest, an officer will generate a preliminary PSA report to determine whether to issue a complaint-summons or a complaint-warrant. ${ }^{80}$ The officer will decide to seek a complaint-warrant based on the charge, the preliminary PSA score, and the attorney general guidelines. ${ }^{81}$ The court releases those issued a complaintsummons with instructions to return to court at a later date..$^{82}$ The court transfers those issued a complaint-warrant to county jail to await a release decision by a judge. ${ }^{83}$ The initial decision to issue a summons or warrant means the difference between immediate release and detention in jail until the court makes a release decision. ${ }^{84}$

If the officer issues a defendant a warrant, pretrial services staff members will prepare a recommendation on conditions of release in accordance with the decisionmaking framework developed by the courts. ${ }^{85}$ Pretrial services staff members complete another PSA, which may include information missing from the preliminary PSA, and apply the decision-making framework to make a recommendation based on the PSA

\footnotetext{
${ }^{79} I d$. at $1-4$.

${ }^{80}$ Chief Justice Stuart Rabner, N.J. Judiciary, Criminal Justice Reform: A SteP-by-Step Guide (Oct. 2019) [hereinafter RABNER, A STEP-BY-STEP GUIDE], https://www.njcourts.gov/forms/12221_cjr_stepbystep.pdf [https://perma.cc/L794-K2DR].

${ }^{81}$ Chloe Anderson et al., MDRC Ctr. for Crim. Just. Rsch., Evaluation of Pretrial Justice System Reforms that Use the Public Safety Assessment: EfFects of New Jersey's Criminal Justice Reform 7 (2019), https://www.mdrc.org/sites/default/files/PSA_New_Jersey_Report_\%231.pdf [https://perma.cc/MF94-LLBC].

${ }^{82}$ RABNER, A STEP-BY-STEP GUIDE, supra note 80, at 2.

${ }^{83} \mathrm{Id}$.

${ }^{84}$ N.J. STAT. ANN. § 2A:162-16(a) (West 2020).

${ }^{85}$ N.J. Judiciary, Pretrial Release Recommendation Decision Making Framework (DMF) (2018), https://www.njcourts.gov/courts/assets/criminal/decmakframwork.pdf [https://perma.cc/QB3W-L9YT].
} 
score and the current charge ${ }^{86}$ Possible recommendations include (1) release on recognizance, (2) release with pretrial monitoring conditions, or (3) no release. ${ }^{87}$

The court then considers the risk assessment results, the Pretrial Services Program's recommendations, and any other information provided by a prosecutor or the defendant to make a release decision. ${ }^{88}$ The court will either release the defendant on personal recognizance, an unsecured appearance bond, or release with the least restrictive nonmonetary conditions that will reasonably assure the following: (1) the defendant appears in court, (2) the community is safe, and (3) the defendant will not obstruct or attempt to obstruct the criminal justice process. ${ }^{89}$ If the court does not find that any of these conditions will assure the defendant's appearance in court, the court may order release on monetary bail, but only to address flight risk..$^{90}$ If the prosecutor files a pretrial detention motion, the court may also detain the defendant in jail pending a pretrial detention hearing. ${ }^{91}$ The court must make a pretrial release decision less than forty-eight hours after defendant's arrest, unless the prosecutor files a pretrial detention motion, in which case the court must schedule a pretrial detention hearing within three business days. ${ }^{92}$

A court may order pretrial detention for a defendant after a hearing if the court finds by clear and convincing evidence that no condition of release would reasonably assure the defendant's appearance in court, the safety of any member of the community, and that the defendant will not obstruct the criminal justice process. ${ }^{93}$ Except for certain violent crimes or any crime for which the defendant would be subject to life imprisonment, there is a rebuttable presumption against ordering pretrial detention. ${ }^{94}$ The statute grants

\footnotetext{
${ }^{86} \mathrm{Id}$.

${ }^{87} \mathrm{Id}$.

${ }^{88}$ N.J. STAT. ANN. § 2A:162-17(a) (West 2020).

${ }^{89} I d . \S 2 \mathrm{~A}: 162-17(\mathrm{~b})$.

${ }^{90} I d$. § 2A:162-17(c); ANDERSON ET AL., supra note 81, at 10 ("Money bail is technically an option at this point, but since CJR was implemented, it is almost never set as an initial release condition.").

${ }^{91}$ N.J. STAT. ANN. § 2A:162-16(d) (West 2020).

${ }^{92}$ RABNER, A STEP-BY-STEP GUIDE, supra note 80.

${ }^{93}$ N.J. STAT. ANN. § 2A:162-18(a)(1) (West 2020).

${ }^{94} I d$. § 2A:162-18(b). There is no rebuttable presumption for charges of first or second degree of the following: murder, aggravated manslaughter or manslaughter, vehicular homicide, aggravated assault,
} 
defendants the right to counsel for pretrial detention hearings. ${ }^{95}$ A defendant may appeal an order of pretrial detention and the appeal must be heard quickly. ${ }^{96}$

\section{b. New Jersey Bail Reform and Domestic Violence}

There are a few provisions in the New Jersey bail statute that address domestic violence cases explicitly. A prosecutor may file a pretrial detention motion for any crime or offense involving domestic violence as defined in the New Jersey Code of Criminal Justice. ${ }^{97}$ If the prosecutor files a pretrial detention motion, a court may order pretrial detention for any crime involving domestic violence after a hearing and based on clear and convincing evidence that no other conditions will assure the defendant's return to court, public safety, and that the defendant will not obstruct the criminal justice process. ${ }^{98}$ Restrictions on cash bail also remain for those charged with domestic violence crimes, ${ }^{99}$ but these restrictions are likely immaterial, as money bail is rarely used as an initial release condition post-reform. ${ }^{100}$

disarming a law enforcement officer, kidnapping, aggravated sexual assault, sexual assault, robbery, carjacking, aggravated arson, burglary, extortion, booby traps in manufacturing or distribution facilities, strict liability for drug induced deaths, terrorism, producing or possessing chemical weapons, biological agents or nuclear or radiological devices, racketeering firearms trafficking, or causing or permitting a child to engage in a prohibited sexual act for an exhibition or performance. Id. $\S \S 2 \mathrm{~A}: 162-19(\mathrm{a})(1), 2 \mathrm{C}: 43-7.2(\mathrm{~d})(1)-(20)$.

${ }^{95}$ Id. $\S 2 \mathrm{~A}: 162-19(\mathrm{e})(1)$.

${ }^{96} I d . \S 2 \mathrm{~A}: 162-18(\mathrm{c})$.

${ }^{97} I d$. § 2A:162-19. Domestic violence includes homicide, assault, terroristic threats, kidnapping, criminal restraint, false imprisonment, sexual assault, criminal sexual contact, lewdness, criminal mischief, burglary, criminal trespass, harassment, stalking, criminal coercion, robbery, contempt of a domestic violence order, cyber-harassment, and any other crime involving risk of death or serious bodily injury to a person covered by this Act. These persons include spouses, former spouses, present or former household members, persons with whom the perpetrator has a child or expecting a child if the victim is pregnant, as well as dating relationships. Victims of domestic violence under the act are eighteen years or older or an emancipated minor. Id. $\S 2 \mathrm{C}: 25-$ 19.

${ }^{98}$ Id. § 2A:162-18(a)(1).

${ }^{99}$ Id. § 2A:162-12.

${ }^{100}$ ANDERSON ET AL., supra note 81, at 4 ("The analysis found only three instances where bail was set as an initial release condition in 2017. Since CJR was implemented, bail is more commonly used for responding to violations or failures to appear for scheduled court events."). 
Following the criminal justice reform, domestic violence advocates expressed concern that the new law did not adequately protect domestic violence victims. ${ }^{101}$ In response, the Attorney General released a directive in September 2017 placing an explicit emphasis on public safety and victims' rights. ${ }^{102}$ The Attorney General Directives establish non-binding guidelines for law enforcement and prosecutorial discretion. ${ }^{103}$ The 2017 AG Directive instructs law enforcement officers to generate a preliminary PSA for domestic violence offenses where the victim has been physically injured, a warrant is in effect, the person has violated a protective order, or a weapon is involved. ${ }^{104}$ The directive instructs officers to seek a complaint-warrant for domestic violence offenses where a protective order appears reasonably necessary to protect the victim. ${ }^{105}$ The directive also commands police officers to complete the Ontario Domestic Assault Risk Assessment (ODARA) for certain domestic violence cases in addition to the preliminary PSA. ${ }^{106}$ ODARA contains thirteen domestic violence-specific risk factors, including the victim's concern for future assault, whether there are children in the relationship, and whether the victim is pregnant. ${ }^{107}$ The directive establishes a presumption that the officer will seek an arrest warrant in cases where the ODARA score is three or higher and a presumption that the prosecutor will seek pretrial detention in cases where the ODARA score is five or higher. ${ }^{108}$ Although the directive clearly states that police officers are to use the ODARA when making decisions to seek complaint-warrants, the judiciary has

\footnotetext{
${ }^{101}$ Marisa Iati, How N.J.'s Attorney General is Trying to Fight Domestic Violence, NJ.com (July 11, 2017), https://www.nj.com/union/2017/07/how_the_nj_attorney_general_is_trying_to_combat_do.html [https://perma.cc/CFT3-X9ZP].

${ }^{102}$ Memorandum from Christopher S. Porrino, Att'y Gen. of New Jersey to Dir., Div. of Crim. Just. et al., Law Enforcement Directive 2016-6: Modification of Directive Establishing Interim Policies, Practices, and Procedures to Implement Criminal Justice Reform Pursuant to P.L. 2015, c. 31, at 14 (Sept. 27, 2017) [hereinafter N.J. Att'y Gen. Memorandum], https://www.nj.gov/lps/dcj/agguide/directives/ag-directive-20166_v3-0.pdf [https://perma.cc/3UES-WXMH] ("[O]ur principal goal in implementing the new statute is to protect the safety of the community, victims, and witnesses.").

${ }^{103} \mathrm{Id}$. at 15 .

${ }^{104} I d$. at 20.

${ }^{105} I d$. at 29

${ }^{106} I d$. at 45 .

${ }^{107} I d$. at 31 .

${ }^{108} I d$. at 2.
} 
advised that it will not use the ODARA tool without legislative authorization. ${ }^{109}$ The legislature has not codified the use of a second risk assessment tool geared toward domestic violence and so judicial officers currently do not consider ODARA scores. Even so, by transitioning to a risk-based model, New Jersey is able to implement bail reform and consider the context of domestic violence crimes when ordering pretrial release conditions or detention.

\section{The New York Approach}

Unlike New Jersey and many of the reforming jurisdictions, New York did not reform its bail framework into a risk-based system. New York State passed bail reform measures in April 2019, eliminating cash bail for most misdemeanors and non-violent felonies. On January 1, 2020, those measures went into effect. Due to backlash primarily concerned with public safety, New York quickly amended the law, expanding the list of bail-eligible offenses. In July 2020, amendments to the bail statute went into effect. In the original reform bill and in the subsequent amendment, New York preserved flight as the only consideration for pretrial release decisions. This section discusses both stages of New York's bail reform.

\section{2019 Criminal Justice Reform}

In April 2019, New York passed bail reform legislation, two years after New Jersey enacted its Bail Reform and Speedy Trial Act. ${ }^{110}$ Criminal justice insiders, however, noticed the inequities of bail administration in New York years before the most recent legislative reform. The New York City Criminal Justice Agency, Inc. (CJA), whose mission is to reduce unnecessary pretrial detention, conducted a research project over ten years beginning in 2002 to research the bail system in New York City. ${ }^{111}$ Public defenders from the Bronx Defenders founded The Bronx Freedom Fund, a charitable bail fund, in 2007 to post bail for low-income New Yorkers after realizing the detrimental

\footnotetext{
109 Id.

${ }^{110}$ RAHMAN, supra note 19 , at 4.

${ }^{111}$ Mary T. Phillips, N.Y.C. Crim. Just. Agency, A Decade of Bail Research in New York City (2012), https://www.prisonpolicy.org/scans/DecadeBailResearch12.pdf. CJA found that there were a "large number of defendants held in jail while awaiting disposition of their cases, in spite of high ROR rates. More than 50,000 defendants are detained annually in New York City only because they lack the money to make bail. Many of them are recommended for release by CJA because of a low risk of failure to appear, and many are not facing jail terms.” N.J. Att'y Gen. Memorandum, supra note 102.
} 
effect unaffordable bail had on their clients' cases. ${ }^{112}$ The 2014 profile on Bronx teenager Kalief Browder ${ }^{113}$ in the New Yorker finally brought the issues of bail in New York to the general public. ${ }^{114}$ Browder had been arrested at age sixteen for allegedly stealing a backpack. Unable to pay the $\$ 3,000$ bail amount, Browder spent three years in Rikers Island Jail pretrial before his case was dismissed. ${ }^{115}$ Much of that time was spent in solitary confinement. ${ }^{116}$ In 2015, Browder took his own life after struggling to adjust to life after Rikers. ${ }^{117}$ While the bail system had been a fact of life for many New Yorkers exposed to the criminal justice system, the publicity surrounding Kalief Browder pushed the inequities of bail administration to the public consciousness.

Public support for bail reform encouraged New York legislators to take steps toward legislative change. Governor Andrew Cuomo announced a set of reforms in January 2018 in his State of the State address, avowing that "Kalief Browder did not die in vain."118 Despite support for bail reform in the New York State Assembly, the Republican-led New York State Senate prevented the state from moving forward with reform. ${ }^{119}$ When a Democratic majority was voted into the New York State Senate in November 2018, bail reform became a realistic legislative goal. ${ }^{120}$

\footnotetext{
112 Tana Ganeva, The Fight to End Cash Bail, 2019 Stan. Soc. Innovation Rev. 18, 18, 21 (Spring) (““We realized bail was a huge driving force of incarceration for our clients,' [Robin Steinberg, founder of Bronx Defenders] says. 'It's the single most powerful coercive lever that got people to plead guilty to crimes, even if they didn’t do it. Even for sums as low as \$250.””).

113 Jennifer Gonnerman, Before the Law, New YoRKER (Oct. 6, 2014), https://www.newyorker.com/magazine/2014/10/06/before-the-law [https://perma.cc/H4PS-ZNF4].

${ }^{114}$ RaHmAn, supra note 19, at 6; see also Jesse McKinley \& Ashley Southall, Kalief Browder's Suicide Inspired a Push to End Cash Bail. Now Lawmakers Have a Deal., N.Y. TiMES (Mar. 29, 2019), https://www.nytimes.com/2019/03/29/nyregion/kalief-browder-cash-bail-reform.html [https://perma.cc/CP9F-LKAR].

${ }^{115}$ Gonnerman, supra note 113.

${ }^{116} I d$

${ }^{117}$ McKinley \& Southall, supra note 114.

${ }^{118}$ RAHMAN, supra note 19 , at 6.

${ }^{119} I d$.

${ }^{120} \mathrm{Id}$. at $6-7$
} 
On April 1, 2019, New York State passed its fiscal year 2020 budget, which included significant legislation on bail reform. The legislation went into effect on January 1, $2020 .{ }^{121}$ Though the reform did not entirely eliminate cash bail, ${ }^{122}$ the new law had the potential to have a transformative impact on mass incarceration in New York. The Vera Institute of Justice conservatively estimated that there would be at least a $40 \%$ reduction in New York's pretrial jail population if the legislation is implemented effectively. ${ }^{123} \mathrm{In}$ comparison, there was a $30.4 \%$ reduction in New Jersey's pretrial jail population as measured two years after New Jersey bail reform went into effect. ${ }^{124}$ Governor Cuomo's office anticipated that in approximately $90 \%$ of cases in New York after the legislation takes effect, persons charged but not yet convicted will remain out of jail before their trials. $^{125}$

The legislation abolished cash bail and pretrial detention in most cases by eliminating cash bail and pretrial detention for almost all misdemeanors and non-violent felonies. ${ }^{126}$ The legislation preserved money bail in almost all violent felony cases. ${ }^{127}$ In lieu of setting bail, courts would release defendants on their own recognizance or subject to nonmonetary release conditions or electronic monitoring. ${ }^{128}$ Non-monetary conditions must be reasonable under the circumstances and may include supervision by a pretrial services agency, restrictions on travel, and orders to refrain from possessing a firearm. ${ }^{129}$ Under

${ }^{121}$ RemPel \& Rodriguez, BAil Reform In NeW York, supra note 20, at 1.

122 RAHMAN, supra note 19, at 4 ("To many interested in bail and pretrial justice, New York's reform seemed un-newsworthy as it didn't go as far as originally promised to eliminate money bail entirely.").

${ }^{123} I d$. (including statistics based on an unpublished analysis of county-level jail data conducted by Vera).

${ }^{124}$ N.J. Admin. OfF. Of the CT., Criminal Justice Reform Data, January 1-December 31, 2018, at 5 (2020), https://www.njcourts.gov/courts/assets/criminal/cjrreport2018.pdf?c=oam [https://perma.cc/88ZZ3DGB].

${ }^{125}$ Governor Cuomo Announces Highlights of FY 2020 Budget, OfF. WeBsite OF N.Y. ST. (Apr. 1, 2019), https://www.governor.ny.gov/news/governor-cuomo-announces-highlights-fy-2020-budget [https://perma.cc/GK5R-7FAF].

${ }^{126}$ ReMPel \& Rodriguez, BAil REForm IN NEW YorK, supra note 20, at 1 (finding that "of the almost 205,000 criminal cases that were arraigned in New York City in 2018, the new legislation leaves money bail as an option in just 10 percent"); see also N.Y. CrIM. Proc. LAW § 500.10(3-a) (McKinney 2020).

${ }^{127}$ ReMPel \& Rodriguez, BAIL REFORM In NEW York, supra note 20, at 1.

${ }^{128} I d$. at 8.

${ }^{129}$ N.Y. CRIM. Proc. LAW $§ 500.10(3-\mathrm{a})$ (McKinney 2020). 
the legislation, the court must order "the least restrictive conditions that will reasonably assure the principal's return to court." ${ }^{130}$ Additionally, the bill preserves the court's ability to issue a temporary order of protection for domestic violence crimes. ${ }^{131}$

While some domestic violence advocates expressed concerns about victims' safety if New York ended its cash bail regime, ${ }^{132}$ the legislation did include some carveouts for some domestic violence cases and sex crimes. The legislation permitted judges to set bail for (1) crimes involving witness intimidation or tampering under sections 215.15, 215.11, 215.12 , or 215.13 of the penal law; ${ }^{133}$ (2) all sex offenses including misdemeanors and non-violent felonies ${ }^{134}$; and (3) criminal contempt when a defendant violates an order of protection and the party protected was a member of the defendant's family or household. ${ }^{135}$ The legislation authorized pretrial detention without bail solely for qualifying felony offenses. ${ }^{136}$

These three exceptions would permit judges to set bail in a number of domestic violence cases. ${ }^{137}$ According to the Center for Court Innovation, had the legislation been in effect in 2018, the three exceptions would have captured 7,539 cases in New York City

\footnotetext{
${ }^{130} \mathrm{Id}$

${ }^{131} I d . \S 530.12(1)$.

${ }^{132}$ Kluger \& Zwang, supra note 22.

${ }^{133}$ N.Y. CRIM. Proc. Law $\S \S 510.10(4)(b)-(c)$ (McKinney 2020). New York Penal Law sections 215.15, $215.11,215.12$, and 215.13 include intimidating a victim or witness in the third degree, tampering with a witness in the third degree, tampering with a witness in the second degree, and tampering with a witness in the first degree, all of which are non-violent felonies. N.Y. PENAL LAW $\S \S 215.15,215.11,215.12,215.13$ (McKinney 2020).
}

${ }^{134}$ N.Y. CRIM. Proc. LAW § 510.10(4)(e) (McKinney 2020).

${ }^{135} I d . \S 510.10(4)(\mathrm{h})$.

${ }^{136} I d . \S 510.10(4)$.

${ }^{137}$ New York penal law does not contain a crime of "domestic violence." Domestic Violence Acts/Crimes, NYCOURTS.GOV, https://www.nycourts.gov/CourtHelp/Safety/DVacts.shtml [https://perma.cc/UNR3-5VN8]. In New York, "domestic violence" is an umbrella term covering a diverse set of crimes committed against an intimate partner or family member. N.Y. CRIM. Proc. LAW $\S \S 530.11(1)(a)-(e)$ (McKinney 2020). 
that year. ${ }^{138} 4,550$ of those cases involved an allegation of domestic violence. ${ }^{139} 2,316$ violent felony cases involving domestic violence would have also qualified for money bail in New York City in 2018. ${ }^{140}$ Nevertheless, judges could not set money bail for a number of domestic violence misdemeanors and non-violent felonies after the reform went into effect. Misdemeanors of assault, aggravated harassment, menacing, stalking, and more against an intimate partner do not qualify for money bail without the presence of another qualifying offense (e.g., violation of a protective order). ${ }^{141}$

A judge could, however, order electronic monitoring for a misdemeanor crime of domestic violence, among other qualifying offenses. ${ }^{142}$ The criminal justice reform introduced electronic monitoring as a non-monetary release condition. ${ }^{143}$ The law specified that notice, an opportunity to be heard, and an individualized determination explained on the record or in writing are required before the court may order electronic monitoring. ${ }^{144}$ The court may order electronic monitoring only after determining that no other non-monetary conditions will reasonably assure the defendant's return to court. ${ }^{145}$

Importantly, although the exceptions permitted bail and electronic monitoring for certain domestic violence cases, the statute contained a presumption of release on recognizance (ROR) for all crimes, including those eligible for bail. ${ }^{146}$ To overcome the

\footnotetext{
${ }^{138}$ Michael Rempel \& Krystal Rodriguez, Ctr. For Ct. Innovation, Bail Reform and Domestic Violence, Implications of New York's New Pretrial Statute 1-2 (2019) [hereinafter Rempel \& RODRIGUEZ, BAIL REFORM AND DOMESTIC VIOLENCE], https://www.courtinnovation.org/sites/default/files/media/document/2019/nys_bail_domestic_violence2.pdf [https://perma.cc/23AH-PGAV].

${ }^{139} I d$.

${ }^{140} I d$. at 2.

${ }^{141}$ See id. at 4-6.

${ }^{142}$ New York Criminal Procedure law defines "misdemeanor crime of domestic violence," for purposes of this section as "a misdemeanor under the penal law provisions and circumstances described in subdivision one of section 530.11 of this title.” N.Y. Crim. Proc. LAW. § 500.10(22) (McKinney 2020).

${ }^{143} I d . \S 500.10(3-\mathrm{a})(\mathrm{j})$.

${ }^{144} I d . \S 510.40(4)$ (a) (amended July 2, 2020).

${ }^{145} I d$.

${ }^{146} I d$. $\S 510.10(1)$ (amended July 2, 2020).
} 
presumption of ROR, the judge must make an individual determination that the defendant poses a flight risk. ${ }^{147}$ If the judge does find that the defendant poses a risk of flight, the court must order the least restrictive alternative and conditions that will reasonably assure the defendant's return to court. ${ }^{148}$ When making this determination, the judge must consider the defendant's activities and history, current charges faced, criminal conviction record, juvenile delinquency record or youthful offender status, and previous record of flight to avoid criminal prosecution. ${ }^{149}$ For offenses that qualify for money bail, the judge must consider financial circumstances and ability to post bail. ${ }^{150}$ When a defendant is charged with domestic violence, the court must consider order of protection violations and the defendant's history of use or possession of a firearm. ${ }^{151}$

\section{2020 Rollbacks}

In April 2020, mere months after New York's criminal justice reform went into effect, the state legislature amended the law following criticism by opponents of reform. ${ }^{152}$ After the laws went into effect, critics cited public safety concerns to roll back the reforms, pointing to anti-Semitic incidents ${ }^{153}$ and NYPD claims that the crime rate was increasing. ${ }^{154}$ In July 2020 , the amended bail statutes went into effect. The current law made more crimes bail-eligible, introduced new non-monetary conditions for release,

\footnotetext{
${ }^{147} I d$.

${ }^{148} I d$.

${ }^{149} I d . \S \S 510.30(1)(\mathrm{a})-(\mathrm{e})$ (amended July 2, 2020).

${ }^{150} I d$. $\S 510.30(1)(f)$ (amended July 2, 2020).

${ }^{151} I d . \S 510.30(1)(\mathrm{g})$ (amended July 2, 2020).
}

${ }^{152}$ See Taryn A. Merkl, New York's Latest Bail Law Changes Explained, BRENNAN CTR. FOR Just. (Apr. 16, 2020), https://www.brennancenter.org/our-work/analysis-opinion/new-yorks-latest-bail-law-changesexplained [https://perma.cc/EM2S—8LRV].

${ }^{153}$ Jesse McKinley \& Jeffery C. May, After Anti-Semitic Incidents, New Bail Law in N.Y. Comes Under Attack, N.Y. TimES (Jan. 8, 2020), https://www.nytimes.com/2020/01/08/nyregion/cash-bail-reform-ny.html [https://perma.cc/F9BH-KUPJ].

${ }^{154}$ Rocco Parascandola \& Leonard Greene, Many Suspects Freed Under Bail Reform Go on to Commit Major Crimes: NYPD, N.Y. DAILY NEws (Mar. 5, 2020), https://www.nydailynews.com/new-york/ny-crimebail-reform-20200305-orj4edxnh5awfojesnohu276mq-story.html?outputType=amp [https://perma.cc/PL6SQH4S]. 
and introduced new public reporting requirements. ${ }^{155}$ The law still does not instruct courts to order release conditions based on public safety or risk-based considerations.

All charges that were bail-eligible under the 2019 bail reform scheme are still baileligible under the new legislation. ${ }^{156}$ The 2020 amendments made additional misdemeanors and nonviolent felonies bail-eligible, including two additional domestic violence crimes ${ }^{157}$ — criminal obstruction of breathing ${ }^{158}$ and unlawful imprisonment in the first degree, if committed as domestic violence offenses. ${ }^{159}$ Additionally, the 2020 amendments explicitly state that strangulation in the second degree is bail-eligible if committed as a domestic violence offense. ${ }^{160}$

The 2019 reforms made non-monetary conditions available for judges to impose pretrial in lieu of money bail. These included electronic monitoring, supervision by a pretrial services agency, and prohibition against possessing a firearm. ${ }^{161}$ The 2020 amendments make additional non-monetary conditions available for judges to impose, including some conditions directed toward domestic violence offenders. Judges may refer defendants to pretrial services programs for placement in mandatory intimate partner violence intervention programs. ${ }^{162}$ Although the defendant shall not be required to pay for

\footnotetext{
${ }^{155}$ Michael Rempel \& Krystal Rodriguez, Ctr. for Ct. Innovation, Bail Reform Revisited: The

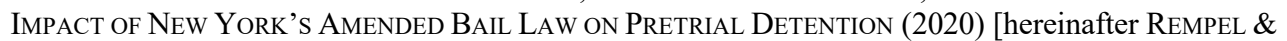
RODRIGUEZ, BAIL REFORM REVISITED], https://www.courtinnovation.org/sites/default/files/media/document/2020/bail_reform_revisited_05272020.p df [https://perma.cc/6PCZ-9XDN].

${ }^{156} I d$. at 2 .

${ }^{157} I d$. The 2020 amendments are often referred to as "rollbacks" because while the 2019 reform made many charges ineligible for bail, the 2020 amendments made some of them bail-eligible again, as they were prereform.

${ }^{158}$ N.Y. CRim. Proc. LaW § 510.10(4)(k) (McKinney 2020); see also Rempel \& RodrigueZ, BAil Reform REVISITED, supra note 155 , at 3.

${ }^{159}$ N.Y. CRIm. Proc. LaW $§ 510.10(4)(k)$ (McKinney 2020); see also Rempel \& Rodriguez, Bail Reform REVISITED, supra note 155 , at 4 .

${ }^{160}$ N.Y. CRim. Proc. LaW $\S 510.10(4)(\mathrm{k})$ (McKinney 2020); see also RemPel \& RodRIGUEZ, BAIL Reform REVISITED, supra note 155 , at 4.

${ }^{161}$ N.Y. CRim. Proc. LAW $§ 500.10(3-a)$ (McKinney 2020).

${ }^{162} I d . \S 500.10(3-\mathrm{a})(\mathrm{f})$.
} 
the cost of any conditions of release, ${ }^{163}$ there is no specific funding for these services. ${ }^{164}$ Judges may also order defendants to obey conditions addressing the victim's safety, including conditions requested by or on behalf of the victim, for a domestic violence offense. ${ }^{165}$ The statute does not specify possible conditions that may address a victim's safety.

Analysis by the Center for Court Innovation suggests that the amended law will result in a 16\% increase in the use of money bail and pretrial detention in New York City criminal cases and $16 \%$ increase in the pretrial bail population, as compared to the reforms passed in $2019 .{ }^{166}$ Even so, the new amended law is expected to significantly curtail pretrial detention as compared to the law before criminal justice reform. ${ }^{167}$

\section{New York Bail Reform May Pose Risks for Victims}

Bail reform is important to rectify inequities in the pretrial system. ${ }^{168}$ Nevertheless, the unique nature of domestic violence crimes may weigh in favor of incorporating specific domestic violence considerations in state bail laws. Part II begins by addressing the harms wrought by domestic violence and the historical background of domestic violence law in New York. It then discusses how the current bail laws may exacerbate the specific harms and risks of domestic violence cases.

\section{A. The Harms of Domestic Violence}

\section{Domestic Violence Is a Widespread Public Health Issue}

Intimate partner violence, known more commonly as "domestic violence," is pervasive in the United States. According to the 2015 National Intimate Partner and

\footnotetext{
${ }^{163} I d . \S 500.10(3-\mathrm{a})$.

${ }^{164}$ Merkl, supra note 152.

${ }^{165}$ N.Y. CRIM. Proc. LAW $§ 500.10(3-a)(i)$ (McKinney 2020).

${ }^{166}$ RemPel \& RodRIGUEZ, BAIL ReFORM Revisited, supra note 155 , at 1.

${ }^{167}$ Id. (“Approximately 84 percent of New York City criminal cases arraigned in 2019 would have been ineligible for bail under the amended statute; and the amendments still allow for an estimated 30 percent reduction in the city's jail population when compared to the absence of any reform.").
}

${ }^{168}$ See supra Part I.B for a brief discussion of the inequities of bail. 
Sexual Violence Survey, ${ }^{169}$ about one in four women and one in ten men experience contact sexual violence, ${ }^{170}$ physical violence, and/or stalking by an intimate partner and reported at least one measure of intimate partner violence-related impact ${ }^{171}$ during their lifetime. Domestic violence is now recognized as a public health issue and widespread societal problem. ${ }^{172}$ Domestic violence causes physical injury, psychological trauma, and even death, and the consequences of intimate partner violence can last long after the abuse ends. ${ }^{173}$ Women who are abused are more likely to experience depression, abuse drugs and alcohol, and attempt suicide than those who are not abused. ${ }^{174}$ One study by the Centers for Disease Control and Prevention (CDC) estimated that the costs of intimate partner rape, physical assault, and stalking exceeded $\$ 5.8$ billion per year, $\$ 4.1$ billion of which were for medical and mental health services. ${ }^{175}$

In New York State, in counties outside of New York City, 29\% of all assaults were committed by intimate partners. ${ }^{176}$ In $79 \%$ of those assaults, women were the victim. ${ }^{177}$ In

\footnotetext{
169 Sharon G. Smith et al., Nat’l Ctr. For Injury Prevention \& Control \& Div. Of Violence Prevention, Ctrs. for Disease Control \& Prevention (CDC), The National Intimate Partner and Sexual Violence SuRvey: 2015 Data Brief - Updated Release (2018), https://www.cdc.gov/violenceprevention/pdf/2015data-brief508.pdf [https://perma.cc/K582-V7U9].
}

${ }^{170} I d$. at 7 (stating that contact sexual violence is a NISVS measure that "includes rape, being made to penetrate someone else, sexual coercion, and unwanted sexual contact")

${ }^{171} I d$. (explaining that intimate partner violence-related impact includes: "being fearful, concerned for safety, injury, need for medical care, needed help from law enforcement, missed at least one day of work, [and] missed at least one day of school"). The lifetime estimate also included "any post-traumatic stress disorder symptoms, need for housing services, need for victim advocate services, need for legal services and contacting a crisis hotline." For those who were raped or made to penetrate someone else, IPV impacts also include a lifetime estimate of STI infection or pregnancy. Id.

172 Dorchen Leidholdt \& Lynn Beller, Domestic Violence and the Law: A New York State-Centric Overview and Update, 2017 N.Y. ST. BAR Ass'N J. 14, 14.

173 Dep’t of Health \& Hum. Servs., Ctrs. For Disease Control \& Prevention (CDC) \& Nat’l Ctr. For Injury Prevention \& Control, Costs of Intimate Partner Violence Against Women in the United STATES 3 (2003), https://www.cdc.gov/violenceprevention/pdf/ipvbook-a.pdf [https://perma.cc/4MUY$8 \mathrm{ETR}]$.

${ }^{174} I d$.

${ }^{175} \mathrm{Id}$. at 2 .

${ }^{176}$ N.Y. St. Off. For the Prevention of Domestic Violence, supra note 23, at 2.

${ }^{177} I d$. 
2018 in New York State, 44\% of female homicide victims who were sixteen years or older were killed by an intimate partner. ${ }^{178}$ During that time, $2 \%$ of male homicide victims over the age of sixteen were killed by an intimate partner. ${ }^{179}$ Though New York has been a leader in the efforts to fight domestic violence, ${ }^{180}$ many New Yorkers are still impacted by violence today.

\section{The Unique Characteristics of Domestic Violence Crimes}

A domestic violence crime is distinct from a stranger crime because of the close relationship between perpetrator and victim. Domestic violence is a systematic pattern of power and control exerted against a single person who is repeatedly targeted. ${ }^{181} \mathrm{~A}$ perpetrator of domestic violence often knows identifying information about the victim and her friends and family, including where they live and work. Perpetrators and victims may even share a residence. These facts suggest that perpetrators of domestic violence have an opportunity to reoffend.

Domestic violence also presents unique temporal risks. Domestic violence organizations identify the moment of separation or threat of separation as the most dangerous time for a victim in an abusive relationship. ${ }^{182}$ Studies have found an increased risk of domestic violence homicide following actual separation or threat of separation. ${ }^{183}$ In an eleven-city study seeking to identify risk factors for femicide in abusive relationships, Jacquelyn Campbell et al. found that "[w]omen who separated from their

\footnotetext{
${ }^{178} I d$.

${ }^{179} I d$.

${ }^{180}$ Leidholdt \& Beller, supra note 172, at 15.

${ }^{181}$ Learn More, NAT'L CoAl. Against Domestic Violence (NCADV) [hereinafter NCADV, Learn More], $\mathrm{http}: / /$ ncadv.org/learn-more [https://perma.cc/9DTU-85QQ] ("[T] he one constant component of domestic violence is one partner's consistent efforts to maintain power and control over the other.").
}

182 Why Do Victims Stay?, NaT'L CoAl. Against Domestic Violence (NCADV), http://ncadv.org/why-dovictims-stay [https://perma.cc/F6KU-RXF4].

${ }^{183}$ Mindy B. Mechanic et al., Intimate Partner Violence and Stalking Behavior: Exploration of Patterns and Correlates in a Sample of Acutely Battered Women, 15 Violence \& Victims 55, 56 (2000); see, e.g., Jacquelyn C. Campbell et al., Risk Factors for Femicide in Abusive Relationships: Results From a Multisite Case Control Study, 93 Am. J. Pub. Health 1089, 1092 (2003) (finding a higher risk of femicide when a victim was separated from an abusive partner after living together); Margo Wilson \& Martin Daly, Spousal Homicide Risk and Estrangement, 8 ViolenCE \& Victims 3, 8 (1993) (finding that women are more likely to be killed by their husbands when separated than when living together). 
abusive partners after cohabitation experienced increased risk of femicide, particularly when the abuser was highly controlling." ${ }^{184}$ Professor Megan Mahoney famously coined the term "separation assault" to refer to the potentially lethal violence occurring upon separation or attempted separation, explaining the difficulty victims may have extricating themselves from abusive relationships. ${ }^{185}$ Professor Mahoney defines separation assault as "the attack on the woman's body and volition in which her partner seeks to prevent her from leaving, retaliate for the separation, or force her to return." 186

One way courts attempt to combat the increased risk and prevent violence is by issuing orders of protection. Some studies have shown that civil orders of protection can be effective means of deterring repeat incidents of domestic violence. ${ }^{187}$ Nevertheless, a court order may not stop a particularly determined offender. ${ }^{188}$ Studies show protective orders lower the risk of violence, but some risk necessarily remains. ${ }^{189}$ One U.S. Department of Justice report advised, "Victims should be encouraged to take out protective orders and retain them but should also be advised that the orders do not deter all abusers and may be more effective when accompanied by criminal prosecution of the

\footnotetext{
${ }^{184}$ Campbell et al., supra note 183, at 1092.
}

${ }^{185}$ Martha R. Mahoney, Legal Images of Battered Women: Redefining the Issue of Separation, 90 MicH. L. REV. 1, 6 (1991).

${ }^{186} I d$. at 65.

${ }^{187}$ Leidholdt \& Beller, supra note 172, at 14, 17.

188 See Rachel Louise Snyder, A Raised Hand, New Yorker (July 15, 2013),

http://www.newyorker.com/magazine/2013/07/22/a-raised-hand [https://perma.cc/AS39-VWPN] (recounting an incident of domestic violence homicide in which the husband killed the wife despite a restraining order against him).

${ }^{189}$ Suraji R. Wagage, Note, When the Consequences Are Life and Death: Pretrial Detention for Domestic Violence Offenders, 7 DreXel L. Rev. 195, 211 (2014); see J. Reid Meloy et al., Domestic Protection Orders and the Prediction of Subsequent Criminality and Violence Toward Protectees, 34 PsYCHOTHERAPY 447, 454 (1997) (finding that mutual protective orders were related to lower rates of re-arrest but that issuance of a non-mutual protective order increased the risk of re-arrest for a domestic violence incident); Judith McFarlane et al., Protection Orders and Intimate Partner Violence: An 18-Month Study of 150 Black, Hispanic, and White Women, 94 Am. J. Pub. Health 613, 616 (2004) (noting that the 149 women who completed the study reported a decrease in violence over the eighteen months of the study but that $44 \%$ of the women granted a two-year protection order reported at least one violation of the order over the eighteenmonth period). 
abuser." ${ }^{190}$ In cases where victims truly fear for their safety, they may assert public displays of loyalty by dropping charges and recanting their statements for selfpreservation. ${ }^{191}$ In the tragic cases, these self-preservation efforts are not enough. ${ }^{192}$ In her book No Visible Bruises, Rachel Louise Snyder recounts a conversation with a domestic violence advocate who said, "[W]e now know it's the ones who don't show up in court, who don't renew the restraining order, who are in the most danger." ${ }^{\prime 193}$ The phenomenon of separation assault suggests that criminal justice responses must be particularly attuned to the higher risks following the separation of perpetrator and victim.

\section{Historically, Domestic Violence Crimes Were Not Taken Seriously}

Domestic violence crimes are additionally unique because of their historic treatment by the criminal justice system. There is a significant history of law enforcement and criminal justice actors declining to treat domestic violence as criminal behavior. Under English common law, husbands had the right to beat their wives under the power of "domestic chastisement," limited only by what was in "reasonable bounds." 194 The husband was responsible for his wife's misbehavior and so the law allowed him to discipline her with physical punishment. ${ }^{195}$ Until as late as the 1990 s, domestic violence was seen as a private family matter and not within the purview of the criminal justice system. ${ }^{196}$ Police were encouraged to "engage in the resolution of conflict ... without reliance upon criminal assault" statutes. ${ }^{197}$ Law enforcement and prosecutors avoided

\footnotetext{
${ }^{190}$ AndRew R. Klein, U.S. Dep’t of Just., Practical Implications of CurRent Domestic Violence RESEARCh: For LAW ENFORCEMENT, ProseCUTORS AND JUdGES 59 (2009), https://www.ncjrs.gov/pdffiles1/nij/225722.pdf [https://perma.cc/DPP2-DK5T].

${ }^{191}$ SNYDER, supra note 25, at 72.

${ }^{192} I d$. at 76 (recounting a domestic violence homicide committed after the wife recanted her statements to police following the husband's release on bail).

${ }^{193}$ Id. at 54 (quoting Kelly Dunne, Jeanne Geiger Crisis Center's chief operating officer).

194 D. Kelly Weisberg \& Susan Frelich Appleton, Modern Family Law Cases and Materials 230 (6th ed. 2015); see 1 William Blackstone, Commentaries 444-45 (7th ed. 1775).

${ }^{195}$ WeISBERG \& APPLETON, supra note 194, at 230.

${ }^{196}$ Leidholdt \& Beller, supra note 172, at 15.

${ }^{197}$ Id. (quoting 1 A.B.A., Project on Standards for Criminal Justice, ABA StandardS For CRiminal Justice (2d ed. 1980)).
} 
bringing cases against men who assaulted their wives to protect familial privacy and promote "domestic harmony." 198

Domestic violence crimes were similarly dismissed in New York. Police attitudes toward domestic violence were not challenged in New York until 1977, when twelve "battered wives" sued the New York City Police Department and Family Court for the systemic failures to arrest husbands for domestic violence. ${ }^{199}$ The plaintiffs alleged that police officers, when called to a husband's assault on his wife and confronted with undeniable physical evidence, would consistently refuse to arrest the husband and would inform the wife that her only remedy was to obtain a Family Court order of protection. ${ }^{200}$ One plaintiff asserted in the complaint that the police came to the scene after her husband "grabbed me by the throat and beat me" and "brandished a straight razor and threatened me with it (and) tore my blouse off my body and gouged my face, neck, shoulders and hands with his nails, in full public view," and that the police informed her "that since this was a 'family matter' there was nothing they could do and that I would have to go to Family Court." ${ }^{201}$ The parties settled after the police agreed to a consent decree to treat domestic violence claims like any other crime. ${ }^{202}$ Nevertheless, the police continued to exercise their discretion to decline to arrest abusers. ${ }^{203}$

It was not until 1994, when New York passed the Family Protection and Domestic Violence Intervention Act of 1994 (DVIA) and the federal government passed the Violence Against Women Act (VAWA), that attitudes toward domestic violence began to meaningfully change. DVIA reduced police discretion by enacting a mandatory arrest policy for felony and criminal contempt cases. ${ }^{204}$ Police behavior began to change in

${ }^{198}$ Reva B. Siegel, “The Rule of Love”: Wife Beating as Prerogative and Privacy, 105 YALE L.J. 2117, 2118 (1996).

199 Bruno v. Codd, 90 Misc. 2d 1047 (N.Y. Sup. Ct. 1977), rev'd on other grounds, 64 A.D.2d 582 (N.Y. App. Div. 1978), aff'd, 47 N.Y.2d 582 (1979).

${ }^{200} I d$. at 1048 .

${ }^{201} \mathrm{Id}$. at 1049 ("If the allegations of the instant complaint buttressed by hundreds of pages of affidavits are true, only the written law has changed; in reality, wife beating is still condoned, if not approved, by some of those charged with protecting its victims.").

${ }^{202}$ Leidholdt \& Beller, supra note 172, at 15.

${ }^{203}$ Id. (citing Sarah Buell, Mandatory Arrest for Domestic Violence, 11 HARV. WomEN's L.J. 213, 219

(1988)).

${ }^{204} \mathrm{Id}$. 
response, leading to more arrests and prosecutions of abusers and less recidivism. ${ }^{205}$ These changes in the criminal justice response to allegations of domestic violence continue to the present day. ${ }^{206}$

\section{B. Risks in the Bail Context}

While domestic violence imposes public health and criminal justice costs on society generally, these offenses implicate unique considerations in the pretrial period. In the bail context, there are two main concerns: (1) that the pretrial period is more dangerous for victims under the new bail laws and (2) that the structure of the reform bill signals to victims that domestic violence is not taken seriously as truly criminal. The next sections will explore these issues in more depth.

\section{The Pretrial Period May Be More Dangerous for Victims Under the New Bail Laws}

Advocates seeking to end domestic violence have criticized the new bail laws for failing to protect victims during a particularly risky time in the cycle of violence. Leading advocates against domestic violence Judy Harris Kluger and Ariel Zwang acknowledge that "we do not need a cash bail system to ensure someone's return to court." ${ }^{207}$ However, they push for a consideration of victims' safety pretrial. "Over and over again, when we speak with our clients, they tell us they want the court to consider the harm that might come to them and other victims if a defendant is released pretrial.,"208

The pretrial period may be risky if it is accompanied by the victim ending the relationship or the perception that the victim is leaving the relationship. If so, the victim may be subject to separation assault - the increased risk of violence in an abusive relationship prompted by the threat of or actual separation. If under the new bail regime, domestic violence defendants are released pretrial who would otherwise be detained on unaffordable bail, those defendants are able to return to the victim relatively soon after the separation. There is a risk that by making it easier for perpetrators of domestic violence to return to their victims, the New York bail reform puts victims in danger at a

\footnotetext{
${ }^{205} I d$.

${ }^{206} I d$.

${ }^{207}$ Kluger \& Zwang, supra note 22.

${ }^{208} I d$.
} 
time when they are at an increased risk of being harmed and where the current judicial remedies may be ineffective.

The period of time immediately following arrest may pose heightened risks of violence, but it also affords an opportunity for service providers to intervene in the cycle of abuse. Time spent away from the offender allows the victim to connect with service providers, including shelters, and implement a safety plan.

\section{Domestic Violence Crimes Are "Real" Crimes}

Advocates against domestic violence also express concern that the structure of the bail reform laws signal to domestic violence victims that their complaints will not be taken seriously by law enforcement or courts. Leah Feldman of Family Services worries that "[v]ictims who experience a lack of protection by the system will be less likely to reach out for help in the future. ${ }^{209}$ This concern is specific to domestic violence crimes, due in part to the past reluctance of criminal justice system to intervene in domestic disputes.

Advocates against domestic violence look at the new bail reform laws today against the historical backdrop of law enforcement failing to take domestic violence claims seriously. The 2020 rollbacks reflect these concerns. Even so, though there are carveouts in the law for some domestic violence crimes, most will be lumped under the umbrella of misdemeanors, crimes that are seen as less "serious" in the statutory scheme. Under the New York reform, cash bail is eliminated for most misdemeanors and non-violent felonies, subject to some exceptions including crimes involving witness tampering, sex offenses, criminal contempt, and domestic violence strangulation. ${ }^{210}$ The exceptions will capture some domestic violence cases, but many cases will not be subject to the exceptions. Misdemeanor assault, aggravated harassment, menacing, and stalking against an intimate partner will not qualify for money bail without the presence of another qualifying offense (e.g., violation of a protective order). ${ }^{211}$ Domestic violence crimes are overwhelmingly charged as misdemeanors, but they are not necessarily lesser offenses. Particularly because domestic violence manifests in a pattern of power and control that

${ }^{209}$ Leah Feldman, Opinion, New York's Bail Reform Ignores Risks to Victims of Domestic Violence, AuBuRnPuB (Dec. 13, 2019), https://auburnpub.com/opinion/columnists/feldman-new-york-s-bail-reformignores-risks-to-victims/article_6eb5d190-2c56-5c46-bf4e-cd8d57d9a4e5.html [https://perma.cc/C7N5GBQZ].

${ }^{210}$ Rempel \& Rodriguez, Bail Reform Revisited, supra note 155 , at 2-3.

${ }^{211}$ See Rempel \& Rodriguez, BAil Reform And Domestic Violence, supra note 138, at 4-6. 
escalates over time, ${ }^{212}$ it is important for victims to seek help or for the system to intervene before the violence becomes more serious or deadly. Grouping domestic violence charges with crimes like petty theft risks communicating to victims that their claims will not be taken seriously. This may lead to victims declining to report crimes if they believe that such reports will be ineffective or even expose them to further harm.

\section{Possible Mitigating Measures}

This Part presents two potential solutions to address domestic violence concerns within a bail reform framework. Part III.A discusses the risk-based model, or the New Jersey model. Part III.B discusses the incorporation of a mandatory cooldown period for defendants charged with domestic violence into the current New York bail regime. Both models address different concerns from relevant stakeholders, though neither model effectively addresses and solves all stakeholder critiques.

\section{A. Implementing the Risk-Based Model in New York}

One way to address the risks of the New York bail reform for domestic violence victims is to adopt a consideration of dangerousness within the pretrial framework. New York is the only state that does not allow courts to consider public safety when making release decisions. ${ }^{213}$ Before the 1970 s, all bail statutes permitted judges to only consider flight risk when setting bail conditions. ${ }^{214}$ Following the era of "tough on crime" rhetoric, the 1984 Bail Reform Act, and the Supreme Court's ruling in Salerno, states began to allow judges to consider public safety when setting bail or imposing pretrial detention. ${ }^{215}$ Many states also adopted preventative detention following the 1984 Act. ${ }^{216}$ In 2012, the New York Criminal Justice Agency (CJA), after a decade of research on bail in New York City, recommended New York legislators consider amending New York bail laws to authorize preventative detention for dangerous defendants. ${ }^{217}$ Such change would require a public safety consideration to be authorized in the bail laws as well.

\footnotetext{
${ }^{212}$ NCADV, Learn More, supra note 181.

${ }^{213}$ RAHMAN, supra note 19 , at 8.

${ }^{214} I d$.

${ }^{215} \mathrm{Id}$.

${ }^{216}$ PHILLIPS, supra note 111, at 25 (noting that in 2010, twenty-seven states allowed preventative detention).

${ }^{217} I d$. at 129 .
} 
There had been debate around adding a public safety provision into the statute in early 2019 before the final bill passed. ${ }^{218}$ Governor Cuomo's original bail proposal included language permitting judges to consider public safety and impose preventative detention if a person "posed a current risk to the physical safety of a reasonably identifiable person or persons. ${ }^{219}$ However, opponents of the provision, including criminal justice reform advocates and several members of the Assembly, pushed back, citing concerns that a public safety consideration would justify even more detention. ${ }^{220}$ Ultimately, the provision did not make it into the 2020 bill and instead bail was preserved for most violent felonies.

The New Jersey statute could serve as a model for the addition of a public safety provision in New York's statute. Unlike New Jersey, New York would not have to approve a constitutional amendment authorizing pretrial detention. The bail clause in the New York Constitution mirrors the bail clause in the Eighth Amendment of the United States Constitution, which does not include a right to bail. ${ }^{221}$ The New York legislature would have to pass new legislation though to amend the bail statutes. The legislation could abolish cash bail for all offenses, including violent felonies. Instead of assigning bail, the court would evaluate the accused based on a set of pre-defined risk factors. For domestic violence cases, the court could look at risk factors tailored to domestic violence risks, such as those used in the ODARA risk assessment in New Jersey. By abolishing cash bail for all offenses, including felonies, the bail laws would no longer signal that domestic violence cases are any less serious than other violent offenses. By implementing a risk-based framework, courts could tailor release conditions to the likelihood the perpetrator will reoffend. For truly extreme cases that score high on a lethality assessment, ${ }^{222}$ the legislature could authorize pretrial detention.

If New York does amend its bail statute to allow for pretrial detention, the legislature should include certain provisions to protect the accused's constitutional rights. Any detention decision should be made after an adversarial hearing, in which the prosecutor must prove by clear and convincing evidence that the accused poses a current risk to the

\footnotetext{
${ }^{218}$ RAHMAN, supra note 19 , at 7.

${ }^{219} I d$. at 8 .

${ }^{220} I d$.

${ }^{221}$ N.Y. CONST. art. 1, § 5 (“Excessive bail shall not be required nor excessive fines imposed.”).

${ }^{222}$ A lethality assessment evaluates certain risk factors to predict cases in which domestic violence is likely to be fatal. See generally Campbell et al., supra note 183.
} 
physical safety of a reasonably identifiable person or persons and that no other condition of release would reasonably assure the safety of such persons. As in New Jersey, there should be a rebuttable presumption of release and defendants should have the right to counsel for pretrial detention hearings. A defendant should have the ability to appeal an order of pretrial detention and the appeal must be heard quickly.

Some criminal justice players have pushed back against amending the law to consider dangerousness. In particular, public defender offices have taken strong stances against a consideration of public safety. After the bail reform was passed, the Bronx Defenders applauded the elimination of cash bail for most people charged with misdemeanors and non-violent felonies but noted, "While we welcome the criminal justice reform provisions in the budget, there is still much work to be done to make this comprehensive vision of criminal justice a reality. ... [P]retrial detention is fundamentally at odds with the presumption of innocence, so we must continue to fight for comprehensive bail reform that ensures robust due process, eliminates wealth- and race-based detention for everyone, and stands firm against the introduction of dangerousness to our bail statute." ${ }^{223}$ Tina Luongo of The Legal Aid Society, Justine Olderman of The Bronx Defenders, and Lisa Schreibersdorf of Brooklyn Defender Services wrote an op-ed in the New York Law Journal warning against a "dangerousness"-based preventative detention scheme. ${ }^{224}$ They explained that "as public defenders, we worry that extending preventative detention to accused New Yorkers based on perceptions of 'dangerousness' would sanction further racial discrimination and bias. It could also mean an increase in the number of people in pretrial detention.",225

Moreover, the dangerousness debate risks placing domestic violence concerns and criminal justice reform directly at odds. Some organizations that serve victims of domestic violence are strongly in favor of bail reform. In April 2020, the New York City Anti-Violence Project (AVP), an organization that serves LGBTQ and HIV-affected survivors of intimate partner violence and hate violence, announced their opposition to

\footnotetext{
${ }^{223}$ Press Release, Justine Olderman, The Bronx Defenders, The Bronx Defenders Applauds Landmark Criminal Justice Reforms (Apr. 1, 2019), https://www.bronxdefenders.org/the-bronx-defenders-applaudslandmark-criminal-justice-reforms/ [https://perma.cc/62ET-NF68].

${ }^{224}$ Tina Luongo, Justine Olderman \& Lisa Schreibersdorf, Opinion, Albany Must Reject Any 'Dangerousness'-Based Preventative Detention Scheme, Law.com: N.Y. L.J. (Mar. 20, 2019), https://www.law.com/newyorklawjournal/2019/03/20/albany-must-reject-any-dangerousness-basedpreventative-detention-scheme/ [https://perma.cc/3YRS-JEDF].

${ }^{225} \mathrm{Id}$.
} 
the rollbacks on the grounds that cash bail harms marginalized survivors of violence. ${ }^{226}$ Survived and Punished NY, a grassroots organization devoted to ending the criminalization of survivors of gender-based violence, criticized the 2019 bail reform legislation before rollbacks were announced for failing to fully eliminate money bail. ${ }^{227}$

\section{B. Incorporating a Cooldown Period into the Current New York Framework}

In light of critiques of a dangerousness consideration in the pretrial framework, an alternate approach to the New Jersey framework is worth considering. New York could pursue bail reform as it has since 2019 by eliminating bail for certain offenses but incorporating provisions directed specifically at the concerns of domestic violence advocates. This Note proposes the incorporation of a cooldown period for persons accused of certain violent domestic violence crimes into the pretrial framework. A cooldown period could be mandated by statute or implemented according to judicial discretion.

Some states have already incorporated statutory provisions on holds for cooldown periods. In Tennessee, defendants arrested for certain domestic violence offenses, "shall not be released within twelve (12) hours of the time of arrest" if the magistrate or other official duly authorized to release the offender finds that the offender is a threat to the alleged victim. ${ }^{228}$ In Mississippi, after setting bail, "the judge may impose on the arrested person a holding period not to exceed twenty-four (24) hours from the time of the initial appearance or setting of bail." ${ }^{229}$ The judge shall consider the potential for future violence, past history of violence between the defendant and alleged victim, the level of

\footnotetext{
${ }^{226}$ Press Release, The New York City Anti-Violence Project, AVP Opposes New York State's Recently Passed Bail Rollbacks Which Will Put Thousands More in Jail, Including Marginalized and Criminalized LGBTQ Survivors of Violence (Apr. 10, 2020), https://avp.org/avp-opposes-new-york-states-bail-rollbacks/ [https://perma.cc/QG76-FXA3] ("As an organization that serves survivors of IPV and hate violence, AVP opposes these rollbacks on the basis that it will harm and jail many more in our community.").
}

227 “Bail Reform” \& Carceral Control: A Critique of New York's New Bail Laws, Survived \& Punished (Feb. 11, 2020), https://survivedandpunished.org/2020/02/11/bail-reform-carceral-control-a-critique-of-newyorks-new-bail-laws/ [https://perma.cc/7SKV-72RS] ("However, even if implemented to its fullest extent, the bail reform is not genuinely transformative because it divides people into categories of deserving/not deserving, it allows for growth in other forms of carceral control aside from traditional jailing, and, ultimately, it does not challenge the premise of pretrial incarceration.").

${ }^{228}$ Tenn. Code AnN. § 40-11-150 (West 2020).

${ }^{229}$ Miss. Code AnN. § 99-5-37 (West 2020). 
violence of the current offense, any threats of future violence, and the existence of any order of protection when setting specific release conditions. ${ }^{230}$

A "cooldown period" or temporary hold may signal to victims that their reports are taken seriously. If victims see real responses to their reports, they may be encouraged to seek help when they need it most. The moment of separation is a particularly dangerous time in the cycle of abuse, and a cooldown period creates a judicially imposed delay, stretching the period that the defendant and victim are separated. With time on which the victim can rely, the victim can implement a safety plan. The time also benefits domestic violence intervention programs to contact victims to intervene in the cycle of abuse.

A temporary hold may also serve the goals of bail reform. Currently, New York bail reform makes exceptions for certain domestic violence crimes, keeping those crimes as bailable offenses under the reform. ${ }^{231}$ The domestic violence offenses that maintain their bail-eligible status, however, merely allow for the setting of bail in those cases, which may result in some defendants immediately posting bail while others remain in jail until case disposition. A temporary hold, on the other hand, is wealth-neutral. If a cooldown period were implemented, New York may be able to ensure the safety of victims without holding a defendant in indefinite pretrial detention, either due to a dangerousness finding, as in the New Jersey model, or due to inability to pay, as is the case for current bailable offenses in New York.

Although pretrial detention has been shown to detrimentally impact defendants, recent studies have shown negative effects occurring in cases where defendants are detained for periods greater than twenty-four hours. A study of misdemeanor defendants in Harris County found defendants more likely to plead guilty, be sentenced to jail, and receive longer sentences when detained for more than seven days. ${ }^{232}$ A study of defendants in Philadelphia found pretrial detention of greater than three days led to an increased likelihood of conviction and longer sentences. ${ }^{233}$ Moreover, some detention is typical in the normal course of post-arrest processing. In New Jersey, defendants may be

\footnotetext{
${ }^{230} I d$

${ }^{231}$ RemPel \& RodRiguez, BAIL Reform Revisited, supra note 155, at 2.

${ }^{232}$ Heaton et al., supra note 51, at 736 (categorizing individuals as detained pretrial when an individual failed to post bond within seven days of a bail hearing).

${ }^{233}$ Stevenson, supra note 56, at 520 (defining "detainee" as a defendant unable to make bail within three days).
} 
detained for up to forty-eight hours before the court makes a pretrial release decision. ${ }^{234}$ If the prosecutor files a pretrial detention motion, a defendant may be detained for up to three business days before a pretrial detention hearing. ${ }^{235}$ In Harris County, Texas, Local Rule 9 allows for individuals to be detained for up to forty-eight hours for a bail hearing. ${ }^{236}$ Even in New York, arrestees may be held in custody for up to twenty-four hours before arraignment, ${ }^{237}$ which is when bail is set. ${ }^{238}$

There are some tensions between domestic violence concerns and bail reform but a wealth-neutral provision that addresses the needs of domestic violence victims may create a fairer, safer, and more just system for all New Yorkers.

\section{CONCLUSION}

New York is currently grappling with the implementation of an equitable pretrial regime while balancing public safety concerns, as evidenced by the 2019 bail reform measures and subsequent 2020 amendments. The 2019 bail reform statute was a significant and progressive step forward for the criminal justice system and the administration of bail. Even with the 2020 amendments, the current bail regime has the potential to have a transformative impact on mass incarceration in New York State by releasing defendants before trial who would otherwise stay in jail merely due to their inability to afford bail. Nevertheless, victims of domestic violence may be vulnerable under the new statutory scheme. One proposal to address these risks is for New York to adopt the New Jersey model, which incorporates a risk-based framework for pretrial release and has begun to incorporate risk assessments tailored to domestic violence risk factors. It is worthwhile, however, to also explore other mitigating measures in light of New York's commitment to pretrial decisions based solely on flight risk. One such measure could be for New York to adopt a mandatory cooldown period for perpetrators of domestic violence. While New York has taken important steps toward a fair and just system for all, it must grapple with whether that system is truly safe for all.

\footnotetext{
${ }^{234}$ RABNER, A STEP-BY-STEP GUIDE, supra note 80.

${ }^{235} \mathrm{Id}$.

${ }^{236}$ Consent Decree at 17, ODonnell v. Harris County, 251 F. Supp. 3d 1052 (S.D. Tex. 2017), aff'd as modified, 892 F.3d 147 (5th Cir. 2018) (No. 16-cv-01414).

${ }^{237}$ People ex rel. Maxian v. Brown, 77 N.Y.2d 422 (1991) (holding that more than twenty-four hours between arrest and arraignment is presumptively unnecessary in violation of CRIM. PROC. LAW $§ 140.20$ (1)).

${ }^{238}$ NYCOURTS.GOV, Arraignments, supra note 27.
} 